\title{
EFFICIENCY OF SLOVAK MUNICIPALITIES' EXPENDITURE ON SERVICES FOR SENIOR CITIZENS
}

\author{
ALENA KAŠČĆKOVÁa, ${ }^{*}$, ZUZANA RIGOVÁa ${ }^{\mathrm{a}}$, KATARÍNA SÝKOROVÁ $^{\mathrm{b}}$ \\ alena.kascakova@umb.sk,zuzana.rigova@umb.sk, katarina.sykorova@umb.sk

\begin{abstract}
a Matej Bel University in Banská Bystrica, Faculty of Economics, Department of Quantitative Methods and Information Systems, Tajovského 10, Banská Bystrica, Slovakia

b Matej Bel University in Banská Bystrica, Faculty of Economics, Department of Public Economics and Regional Development, Tajovského 10, Banská Bystrica, Slovakia
\end{abstract}

\begin{abstract}
Efficiency in using resources to achieve desired results at the lowest possible cost is not important only for profit-making subjects, but also for non-profit subjects. Economic efficiency of public administration is a permanent topic in Slovakia. Local self-government, represented by municipalities, is an important part of public administration and deals with questions of local importance. In the context of population ageing, the issue of funding care needs of the elderly is addressed in this paper. The paper describes and analyzes social-related expenditures in Slovakia, especially those for taking care of older people in municipalities. It studies the efficiency of Slovak municipalities in allocating financial resources to satisfy potential needs of their seniors by using appropriate mathematical and statistical methods.
\end{abstract}

\section{Key words}

efficiency, municipality, data envelopment analysis, ageing

\section{JEL classification \\ C14, H11, J14, R5}

\section{Introduction}

Population ageing is one of the most significant demographic and social trends of the $21^{\text {st }}$ century, affecting many countries in the world. The Prognostic Institute of the Slovak Academy of Sciences states that it is unequivocally possible to say that in the coming years, in the Slovak Republic is expected a dynamic aging of its population caused mainly by the shifting of large generations to senior age. According to the forecast, the average age of the population by 2025 will approach 43 years. It is expected that from 2018 seniors will prevail over the child component of the population in Slovak Republic and this trend should be maintained until 2030.

The scope and impact of this process can be partially regulated and reduced through socially appropriate arrangements taken in a good time. In view of the above, an increasing demand for social services is expected, but also an increasing demand for the quality of their provision, according to the document National priorities for the development of social services for 2015 - 2020 (2014).

One of the mediators of the provision of social services in Slovakia are municipalities, which manage a limited source of income, from which they realize expenses in a diverse structure. Given limited financial municipalities' resources, the issue of the efficiency of their management becomes important.

Generally, an efficiency of a local government is expressed as the relation between input resources and their economic and social impacts. An expression of public administration efficiency is not a simple task since public services are primarily based on the non-market 
principles and service production inputs and outputs are mostly measured in different metric units. This is an ideal space for the application of DEA methods which are suitable, particularly, for efficiency analysis of the non-profitable subjects (Hužvár et al., 2016).

DEA has been applied for the assessment of relative efficiency of municipality performance in several countries and these approaches and results are presented in many studies. A nice survey of these studies, which were done to the year 2006 is given by Kutlar et al. (2012). These authors applied DEA and Malmquist Index technique to the 27 municipalities in Turkey and they included financial and the fiscal data describing the municipality as the inputs and mainly demographical data as the outputs to their analysis. Benito at al. (2011) analysed and compared the effectiveness of waste management system (public street cleaning and refuse collection services) in 1072 municipalities in Spain. They considered per capita income, population density, comparative index of the tourism and the total economic activity of the observed municipalities to their analysis. D'Inverno et al. (2018) studied the public expenditure efficiency of 282 Tuscan municipalities in five strategic functions: general administration, educational and social services, road maintenance and local mobility and local police services in the first step, as well as overall expenditure efficiency and global spending efficiency in the second and third step. Authors Narbón-Perpina et al. (2019) observed overall cost efficiency in 1574 Spanish municipalities during the period of the economic crises (in years 2008 - 2013) by using four different non parametric methods (DEA, FDH, order-m frontier, Bias corrected DEA estimator of Kneip). Due to great services package and facilities that municipalities must provide the authors designed three different output oriented models in which they included measures of the quantity as well as the quality. They involved various municipal expenditures as inputs and ten variables as outputs. Output indicators of population size, public street infrastructure and lightning, waste collection, supply of drinking water, sewage system, a surface area of public parks, libraries, markets and sport facilities were adjusted also with the respect to the three quality categories (weights for good, fair, bad).

In our paper we look at one fundamental municipal function (original power or competency) which is ensuring the social services, specifically seniors care, i.e. we analyse the relative efficiency level of the services volume provided by the municipality to its inhabitants that attained the age of 62 years and over. Although in this case it is not traditional production process in which efficiency is considered in terms of transforming personal and material resources into final product, we use DEA method. We observe a process in which we allocate the financial resources to fulfil the demand for services generated by a given age group of seniors. They contribute to the production process by generating demands for the special services (e.g. community care), while municipality provides them from its income, of course, in varying degree/level. Therefore, the total demand for services estimated by the number of seniors is considered as an input, while the total amount of finance that are really spent on these services is considered as output in our context. It is assumed that municipality which spends a greater amount of money to provide a greater volume of services for a given number of seniors will be more efficient. While analysing the efficiency of this process, it is important to look at the demographic situation and municipal financing in Slovakia.

\section{Demographic situation in Slovakia}

Current population development in Slovakia should be seen in the context of global population development. Our population is undergoing developmental stages similar to other world populations. Although a number of demographic processes take place in Slovakia with a time delay, although certain demographic specificities have been resolved in Slovakia, our demographic problems are now very similar to those of advanced Western countries. 
In Europe, the population growth is slow with very low natural increase and accompanied by longer life expectancy. Ageing reflects in changes of population structure. Rising proportion of the older age groups in Europe is the result of four main demographic trends (Páleník, 2012). Firstly, fertility rate is well below the survival limit for keeping at least stagnating trend of population growth. The average number of children per woman is 1.59 in Europe (EU 28) in 2017 with the number even lower in Slovakia - 1.52. Secondly, post war baby boom resulted in a high increase of the population that is now getting into the retiring age. The share and number of people over 60 is rising more and more quickly. In addition, life expectancy at birth is rising too, with 78.3 years for men and 83.5 for women in 2017 (73.8 for men and 80.7 for women in Slovakia, in 2017). Finally, growing immigration leads to the heterogeneity of European population and only partially compensates for low fertility rate and high proportion of the older population.

As noted above, the long term decline of both natality and fertility levels in Europe have caused changes in the population age structure. Not only the proportion of pre-productive population is decreasing, but also the proportion of population in the productive age under 50 is stagnating or decreasing slightly. In Slovakia the proportion of people aged $20-49$ years was $45.8 \%$ in 2009 and $43.9 \%$ in 2018 .

Figure 1: Comparison of age groups proportion in EU and Slovakia in 2018 (in \%)

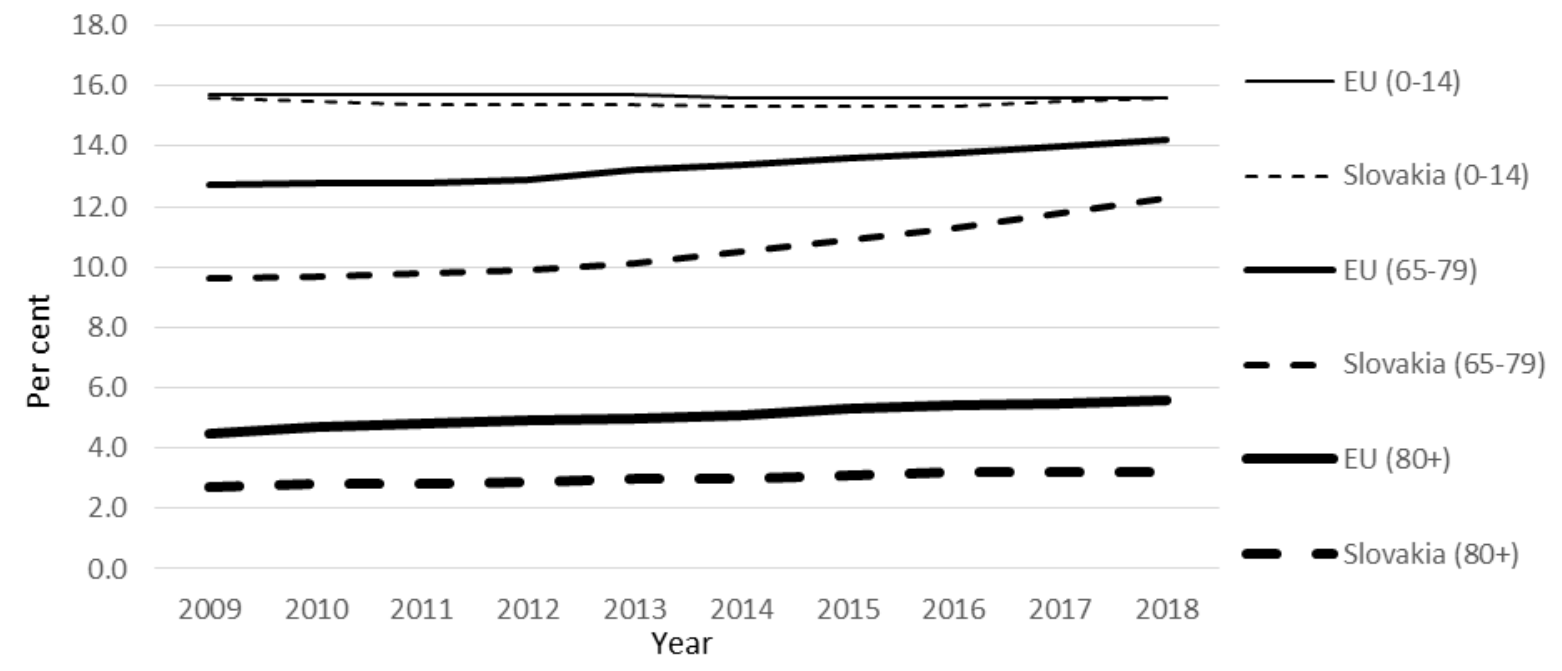

Source: the authors based on data from Eurostat.

On the contrary, the population cohort of over 65 is growing in number and its ratio to the overall population. In Slovakia it has increased from $12.2 \%$ to $15.5 \%$ in the last 10 years. As at 31 December 2017, the Slovak Republic had 844855 seniors in the 65+, and since 2011, this number has grown rapidly, by $3.6 \%$ per year on average.

The above mentioned changes are also reflected in the growth of old-dependency-ratio, i.e. the ratio of the population 65 and over to population 15 to 64 years, which reached the average of 30.5\% in the EU 28 countries in 2018 (Table 1). This indicator was the highest in Italy $(35.2 \%)$ and in Portugal (33.3\%). In Slovakia, this ratio is $22.5 \%$ and its growth is expected to be rapidly accelerating also in the future.

One of the most significant trends of the 21 st century will be the dynamics of the aging process, which can be seen as an increase in the number and share of older people in the population. According to Eurostat's forecast, Slovakia's population will be aging most intensively from all European Union countries. In less than 50 years, Slovakia will change from one of the youngest countries in the European Union (currently the third youngest country to Ireland and Cyprus) to one of the oldest countries (in 2060, only Portugal will have 
older population than Slovakia). The average age of the Slovak population by 2060 will increase by 9 years, i.e. by $24 \%$ and will get close to 50 years (Vaňo, 2015).

The aging index will be around 200 in 2050, and in 2060, about 220 seniors aged 65 and over will account for 100 children under the age of 15 (currently almost 100 seniors per 100 children).

In the context of ageing baby-boomers, declining fertility rates and increasing life expectancies, older people are coming to represent a proportionately larger share of the total population, presenting social, economic and cultural challenges to individuals, families, public welfare systems and societies.

Table 1: Changes in some demographic indicators in chosen EU countries

\begin{tabular}{ccccccccc}
\hline & \multicolumn{2}{c}{ Total fertility rate } & \multicolumn{2}{c}{$\begin{array}{c}\text { Ageing index } \\
(\%)\end{array}$} & \multicolumn{2}{c}{$\begin{array}{c}\text { Old dependency ratio } \\
(\%)\end{array}$} & \multicolumn{2}{c}{$\begin{array}{c}\text { Life expectancy } \\
\text { at birth (years) }\end{array}$} \\
\cline { 2 - 10 } & 2009 & 2017 & 2009 & 2018 & 2009 & 2018 & 2009 & 2017 \\
\hline $\begin{array}{c}\text { European Union } \\
\text { - 28 countries }\end{array}$ & 1.61 & 1.59 & 110.2 & 126.3 & 25.8 & 30.5 & 79.6 & 80.9 \\
$\quad$ Slovakia & 1.44 & 1.52 & 78.2 & 99.4 & 17.0 & 22.5 & 75.3 & 77.3 \\
Czechia & 1.51 & 1.69 & 104.9 & 122.3 & 21.1 & 29.6 & 77.4 & 79.1 \\
Poland & 1.40 & 1.48 & 88.2 & 112.5 & 18.9 & 25.3 & 75.9 & 77.8 \\
Spain & 1.38 & 1.31 & 112.2 & 128.0 & 24.1 & 29.2 & 81.9 & 83.4 \\
Italy & 1.45 & 1.32 & 144.0 & 168.7 & 30.9 & 35.2 & 81.8 & 83.1 \\
\hline
\end{tabular}

Source: the authors based on data from Eurostat.

\section{Competencies and financing of local government in the Slovak Republic}

Municipalities in Slovakia are responsible for execution of more than 4300 competencies in various areas such as education, community care - social services, public healthcare, culture, environment etc. In general, the powers are divided in two groups - original powers and the transferred execution of state administration powers.

In Slovakia, for municipalities and their local governments is very important to ensure sufficient financial sources, intended primarily to finance local government competencies. There is a huge number of original and transferred competencies of self-governments to manage defined area as effectively as possible for its inhabitants (Liptáková, 2018, p. 56).

Original powers are defined in paragraph 3 act no. 369/1990 Coll. of acts on municipal constitution. The process of powers decentralization has started in $2002-2004$ according the act No. 416/2001 Coll. of acts on transfer of certain powers from state administration bodies to municipalities and higher territorial units and it has not been completed yet. Original powers are financed mostly but not only from person income tax and execution of state administration powers are financed by specific subsidies from state budget to lower levels of public administration. The person income tax is a share tax - assigned to municipalities (70\% of the tax yield) and higher territorial units (30\% of the tax yield)

The yield of income tax assigned to municipalities is divided according to following formula:

- $23 \%$ according to the number of inhabitants with permanent residence in the territory of the municipality adjusted by the coefficient of elevation,

- $32 \%$ according to the number of inhabitants with permanent residence in the territory of the municipality adjusted by the size coefficient,

- $40 \%$ according to the number of pupils (children) of Elementary Art Schools and school facilities (except basic schools),

- 5\% according to the number of municipality inhabitants aged 62 years and over (according to act No. 564/2004 Coll. of Acts on budget determination of income tax yields to regional self-government and on amendments and supplements to certain laws 
and Decree of the Government No. 668/2004 Coll. of Acts on distribution of income tax yields to the local government).

Except person income tax, municipalities have other income sources. Other relevant sources of revenues are real estate tax, revenues from own property utilization (sale and lease) and revenues from providing specific services to residents and non-residents. Municipalities can apply for funds from state budget or European community funds. However, person income tax is the most significant income source.

According to the current population ageing process, that is typical for most European countries, we decided to analyze the efficiency of local municipalities in providing original power social services according to act no. 448/2008 Coll. of Acts on social services domiciliary services and other related social services. This group of expenses contains expenditures on domiciliary service provided in residents' households (wages and other payments, material consumption etc.), financing of retirements homes operation, financing homes of domiciliary service, contributions from municipal budget to nonpublic providers of social services, social consulting service. Smaller part of expenses creates social contributions and benefits for residents in specific situations.

\section{Data and methodology}

In Slovakia there are 2927 municipalities with a city, village or military district status, of course with the various number of the inhabitants and belonging to the one of the eight Slovak regions. The problem of municipality services assessment is that there does not exist publicly available information about their quality, so just quantitative data have been included in our analysis. Our data was provided by Slovak DataCentrum (mainly financial indicators of municipality incomes and expenses in year 2017, in the structure of size categories by municipality population and categorized according to the functional and economic classification) and from Statistical Office of Slovak Republic (size groups of municipalities by number of inhabitants in year 2017).

We excluded Bratislava and Košice cities from our analysis, as well as the municipalities with the number of inhabitants less than 100. Bratislava and Košice belong to the cities with the total population more than 100000 , but they are divided into the national administrative district and into city parts with their own local governments which provide services for less than 100000 inhabitants. The villages with the population size to 99 are excluded because of the fact that their main income (share of personal income tax) hardly covers the operational costs of the municipality and so there is no space for the other expenses.

Finally, 2751 municipalities are incorporated into our analysis. In our paper, we group them into the following intervals by number of inhabitants: from 100 to 499,500 to 999 , 1000 to 2999,3000 to 4999,5000 to 9999,10000 to 19999,20000 to 49999 and the last interval 50000 to 99 999. In the following, we mention only the upper limit of the intervals, i.e. $-499,-999,-2999$ etc.

Due to the structure of data from DataCentrum we grouped municipalities by the total number of inhabitants in a municipality and by the region. So, we created 62 groups of the municipalities for our analysis, region-size categories. Table 2 shows the number of the municipalities included in our region-size categories.

Selection of the suitable inputs and outputs is the crucial point for DEA analysis. We assume that the population aged 62 years and over is our input (the age limit is based on the state financial system of the local governments which is mentioned above), since the number of the seniors represents the services demands. The old age expenses, the whole subclass of FK RK ${ }^{1} 1020$ in the financial statement of the municipalities, including budget organizations

\footnotetext{
${ }^{1}$ Functional classification of budget classification.
} 
established by municipality will be our output, i.e. they represent the volume of services provided by municipality for elderly people. Since observed region-size categories consist of different number of municipalities we use inputs and outputs recalculated per one municipality in next analysis.

Table 2: Region-size categories frequencies

\begin{tabular}{cccccccccc}
\hline Region/Size & -499 & -999 & -2999 & -4999 & -9999 & -19999 & -49999 & -99999 & Total \\
\hline BA & 5 & 11 & 39 & 5 & 6 & 3 & 1 & - & 70 \\
TT & 46 & 70 & 104 & 14 & 6 & 5 & 4 & 1 & 250 \\
TN & 77 & 83 & 81 & 15 & 4 & 5 & 5 & 1 & 271 \\
NR & 96 & 98 & 126 & 13 & 8 & 3 & 5 & 1 & 350 \\
ZA & 83 & 73 & 107 & 20 & 13 & 3 & 3 & 2 & 304 \\
BB & 245 & 131 & 83 & 8 & 9 & 6 & 4 & 1 & 487 \\
PO & 288 & 151 & 112 & 16 & 7 & 6 & 4 & 2 & 586 \\
KE & 171 & 134 & 99 & 15 & 9 & 2 & 3 & - & 433 \\
Total & 1011 & 751 & 751 & 106 & 62 & 33 & 29 & 8 & 2751 \\
\hline
\end{tabular}

Notes: BA - Bratislava Region, TT - Trnava Region, TN - Trenčín Region, NR - Nitra Region, ZA - Žilina Region, BB - Banská Bystrica Region, PO - Prešov Region, KE - Košice Region.

Source: the authors based on data from DataCentrum.

We can see in Table 3 that only $28 \%$ of municipalities reported any financial item in old age expenses category. In the group of municipalities with the population size over 9999 almost $100 \%$ of them reported old age expenditures. The worst situation is in the case of municipalities with the population size 100 - 499, where only $10 \%$ of municipalities (101 municipalities from 1011 ) in this size reported old age expenditures.

Table 3: Proportion of the municipalities which reported old age expenditures (in \%)

\begin{tabular}{cccccccccc}
\hline $\begin{array}{c}\text { Region/ Size } \\
\text { category }\end{array}$ & -499 & -999 & -2999 & -4999 & -9999 & -19999 & -49999 & -99999 & Total \\
\hline BA & 40.0 & 27.3 & 33.3 & 100.0 & 83.3 & 100 & 100 & - & 45.7 \\
TT & 19.6 & 28.6 & 37.5 & 57.1 & 83.3 & 100 & 75.0 & 100 & 36.0 \\
TN & 10.4 & 21.7 & 54.3 & 86.7 & 100 & 100 & 100 & 100 & 36.2 \\
NR & 15.6 & 25.5 & 42.1 & 61.5 & 100 & 100 & 100 & 100 & 33.7 \\
ZA & 12.0 & 37.0 & 59.8 & 80.0 & 92.3 & 100 & 100 & 100 & 45.1 \\
BB & 7.3 & 24.4 & 42.2 & 75.0 & 100 & 100 & 100 & 100 & 22.8 \\
PO & 9.7 & 19.9 & 27.7 & 68.8 & 71.4 & 100 & 100 & 100 & 20.0 \\
KE & 6.4 & 9.7 & 24.2 & 46.7 & 77.8 & 100 & 100 & - & 15.5 \\
Total & 10.0 & 22.4 & 40.3 & 69.8 & 88.7 & 100 & 96.6 & 100 & 28.0 \\
\hline
\end{tabular}

Notes: BA - Bratislava Region, TT - Trnava Region, TN - Trenčín Region, NR - Nitra Region, ZA - Žilina Region, BB - Banská Bystrica Region, PO - Prešov Region, KE - Košice Region.

Source: the authors.

Table 4: Average old-age expenses per municipality (in thousands $€$ )

\begin{tabular}{cccccccccc}
\hline Region/ Size category & -499 & -999 & -2999 & -4999 & -9999 & -19999 & -49999 & -99999 & Total \\
\hline BA & $\mathbf{3 . 7 6}$ & 3.12 & 21.94 & $\mathbf{9 5 . 2 5}$ & 126.92 & $\mathbf{5 9 8 . 1 8}$ & 494.22 & - & $\mathbf{6 3 . 3 6}$ \\
TT & $\mathbf{1 . 3 9}$ & $\mathbf{1 6 . 7 9}$ & $\mathbf{3 9 . 6 4}$ & 51.53 & $\mathbf{3 7 5 . 0 5}$ & $\mathbf{8 9 1 . 7 7}$ & 901.32 & $\mathbf{4 0 3 5 . 5 2}$ & $\mathbf{8 1 . 7 3}$ \\
TN & 0.63 & 5.78 & 27.15 & $\mathbf{1 2 0 . 3 6}$ & $\mathbf{2 2 9 . 6 7}$ & 474.44 & $\mathbf{1 4 9 5 . 0 1}$ & 579.46 & 58.59 \\
NR & 0.92 & $\mathbf{2 0 . 4 9}$ & 22.84 & 74.20 & 181.40 & 458.19 & 780.94 & 1621.31 & 40.83 \\
ZA & 0.42 & 1.83 & $\mathbf{2 9 . 9 2}$ & 68.70 & 196.53 & 476.86 & 589.84 & 1626.54 & 45.24 \\
BB & 1.35 & 14.18 & 15.79 & 79.67 & 125.16 & 265.61 & 444.48 & 3212.55 & 24.33 \\
PO & 0.50 & 5.53 & 8.09 & 36.28 & 150.19 & 419.88 & 1043.31 & $\mathbf{3 6 4 0 . 1 9}$ & 29.85 \\
KE & 0.78 & 1.09 & 10.65 & 49.60 & 105.10 & 292.29 & $\mathbf{1 6 7 1 . 4 3}$ & - & 19.91 \\
Total & 0.85 & 8.88 & 22.01 & 68.90 & 178.39 & 488.73 & 972.90 & 2497.79 & \\
\hline
\end{tabular}

Notes: BA - Bratislava Region, TT - Trnava Region, TN - Trenčín Region, NR - Nitra Region, ZA - Žilina Region, BB - Banská Bystrica Region, PO - Prešov Region, KE - Košice Region.

Source: the authors. 
In Table 4 are shown old age expenses per municipality that represent the output of our analysis. For each population size are highlighted two values with the lowest old age expenses (grey background colour) and two with the highest values of this indicator (bold italic font). The totals are weighted averages adjusted with the respect to the total number of the municipalities in the respective population size (last row) and region (last column). It is natural, the lowest old age expenses are observed in the small municipalities to 999 inhabitants, and the highest expenses have municipalities with more than 19999 inhabitants. From the perspective of the regions the lowest old age expenses exhibit Banská Bystrica and Košice regions and the highest expenses are in Bratislava and Trnava regions.

When we examine efficiency of decision making units (DMUs, which are denoted as region-size categories in our analysis) with multiple inputs and outputs by using DEA approach, we create the ratio of weighted inputs to weighted outputs (or vice versa). DEA assigns a best set of input and output weights to each DMU. It means that resulting weighted input to output ratio for each DMU is maximized (or minimized) relative to all other DMUs when these weights are assigned to these inputs and outputs for every DMU (Cooper et al., 2007).

It is supposed that not all seniors aged 62 years and over (62+) have the same intensity and volume of demands for social care, so we divided one input into three seniors' age groups $62-69,70-79$ and 80 and over (80+) and by using weights we emphasize their different importance. Due to this fact we apply Assurance region (thereinafter AR) DEA model. Just AR model allows us to set the weights constraints to limit the region of weights for individual inputs or outputs, thus we can distinguish the importance of considered age categories with the relative magnitude of their weights (see detail in Cooper et al., 2007).

The final scores for region-size categories are computed by using output oriented AR model (AR-O-V) under the variable returns to scale (VRTS). Input, output variables and their descriptions are listed in Table 5.

Table 5: Input and output variables in the model

\begin{tabular}{ccc}
\hline & Indicators & Description \\
\hline \multirow{3}{*}{ Inputs } & (I) Age Category 62-69 & Average number of seniors in respective age category in \\
& (I) Age Category 70-79 & region-size category per municipality \\
(I) Age Category 80+ & Average expenses of municipalities for covering legitimate \\
Output & (O) Old-age expenses & $\begin{array}{c}\text { demands of seniors for specific services, eventually } \\
\text { financial assistance per municipality }\end{array}$ \\
\hline
\end{tabular}

Source: the authors.

Table 6: Correlations between inputs and output variables

\begin{tabular}{ccccc}
\hline & Age Category & Age Category & Age Category & Old-age expenses \\
\hline Age Category 62-69 & $62-69$ & $70-79$ & $80+$ & 0.991 \\
Age Category 70-79 & 1 & 0.998 & 0.996 & 0.871 \\
Age Category 80+ & 0.998 & 1 & 1 & 0.854 \\
Old-age expenses & 0.991 & 0.996 & 0.820 & 0.820 \\
\hline
\end{tabular}

Source: the authors.

Correlations between inputs and output, computed by Pearson's correlation coefficient, are listed in Table 6. The correlation between three age categories is relatively high. These subgroups together create one age group $62+$. Due to the natural mortality of the population, the number of the first age group decreases gradually and relatively equally, what causes a high correlation between these age groups.

In our model, we assume that the members of the older age group require at the least the same volume of services as the members of younger age group. On the contrary, the total 
volume of services required by the members of age groups 70-79 and $80+$ is expected to be at most 1.5 and 2 times greater than the volume of the services by the members of age group $62-69$, respectively.

\section{Results}

Table 7 shows the results of the evaluation of 62 region-size categories by using AR-O-V model. Overall results for this analysis are following: 4 region-size categories are efficient, average score is 0.420 , standard deviation is 0.257 , maximum value of reached scores is naturally 1 and minimum value is 0.042 .

They are up to three efficient region-size categories in Trnava region and one in Banská Bystrica region. There are emphasized two maximum values of the score by using bold italic font and two minimum values by using grey background colour in each size category. In last row and column of the table are totals, which express weighted averages adjusted with the respect to the total number of the municipalities belonging to the respective region-size category.

Table 7: Efficiency scores of the observed region-size categories

\begin{tabular}{cccccccccc}
\hline Region/ Size category & -499 & -999 & -2999 & -4999 & -9999 & -19999 & -49999 & -99999 & Total \\
\hline BA & $\mathbf{0 , 8 4}$ & 0.11 & 0.24 & $\mathbf{0 . 5 3}$ & 0.32 & $\mathbf{0 . 7 0}$ & 0.25 & & 0.31 \\
TT & 0.14 & $\mathbf{0 . 5 5}$ & $\mathbf{0 . 4 3}$ & 0.24 & $\mathbf{1}$ & $\mathbf{1}$ & 0.56 & $\mathbf{1}$ & $\mathbf{0 . 4 3}$ \\
TN & 0.09 & 0.18 & 0.28 & $\mathbf{0 . 4 7}$ & 0.51 & 0.46 & $\mathbf{0 . 7 8}$ & 0.15 & 0.22 \\
NR & 0.12 & $\mathbf{0 . 6 0}$ & 0.24 & 0.31 & 0.39 & 0.56 & 0.40 & 0.40 & 0.32 \\
ZA & 0.15 & 0.07 & $\mathbf{0 . 3 8}$ & 0.35 & $\mathbf{0 . 5 3}$ & 0.53 & 0.35 & 0.40 & 0.25 \\
BB & $\mathbf{1}$ & 0.51 & 0.18 & 0.33 & 0.29 & 0.31 & 0.24 & 0.80 & $\mathbf{0 . 6 9}$ \\
PO & 0.24 & 0.24 & 0.13 & 0.24 & 0.50 & 0.56 & 0.64 & $\mathbf{0 . 9 0}$ & 0.23 \\
KE & 0.19 & 0.04 & 0.15 & 0.33 & 0.33 & 0.34 & $\mathbf{0 . 9 8}$ & & 0.15 \\
Total & 0.38 & 0.30 & 0.26 & 0.33 & 0.47 & $\mathbf{0 . 5 6}$ & 0.55 & $\mathbf{0 . 6 2}$ & \\
\hline
\end{tabular}

Notes: BA - Bratislava Region, TT - Trnava Region, TN - Trenčín Region, NR - Nitra Region, ZA - Žilina Region, BB - Banská Bystrica Region, PO - Prešov Region, KE - Košice Region.

Source: the authors.

Regarding to the size category of the municipalities we can observe the relatively small scores in small population size municipalities, even category size to 999 and 2999 inhabitants are size categories with two smallest values of their totals $(0.30$ and 0.26$)$. The highest totals (0.56 and 0.62) were reached in size category to 19999 and to 99999 inhabitants.

Regarding to the regions relatively the worst results were reached in Trenčín and Košice regions with the smallest scores of the totals 0.22 and 0.15 and the best ones in Trnava and Banská Bystrica regions, see values 0.43 and 0.69. Surprisingly, in case of Banská Bystrica region, which reached the best total from the regions point of view (0.69), there are up to three region-size categories which exhibit one of two the smallest values in respective size category (size to 9999 , to 19999 and to 49999 inhabitants). There are two region-size categories in the size category to 999 inhabitants in Žilina and Košice regions which reached the smallest scores (0.07 and 0.04). There is the significant relation between final scores and old age expenses of the respective region-size categories indicated by the correlation coefficient 0.575 .

Figure 2 represents results (adjusted efficiency scores) from the size category point of view.

Finally we conclude that relatively better scores achieved municipalities with higher population size, what is probably caused by the fact that the main income of these municipalities, personal income tax, creates the space not only to cover operating costs of the municipality, but also other expenses. Obviously, these municipalities have a bigger space to obtain other incomes - e.g. local taxes. 
Figure 2: Adjusted efficiency scores by municipality population size

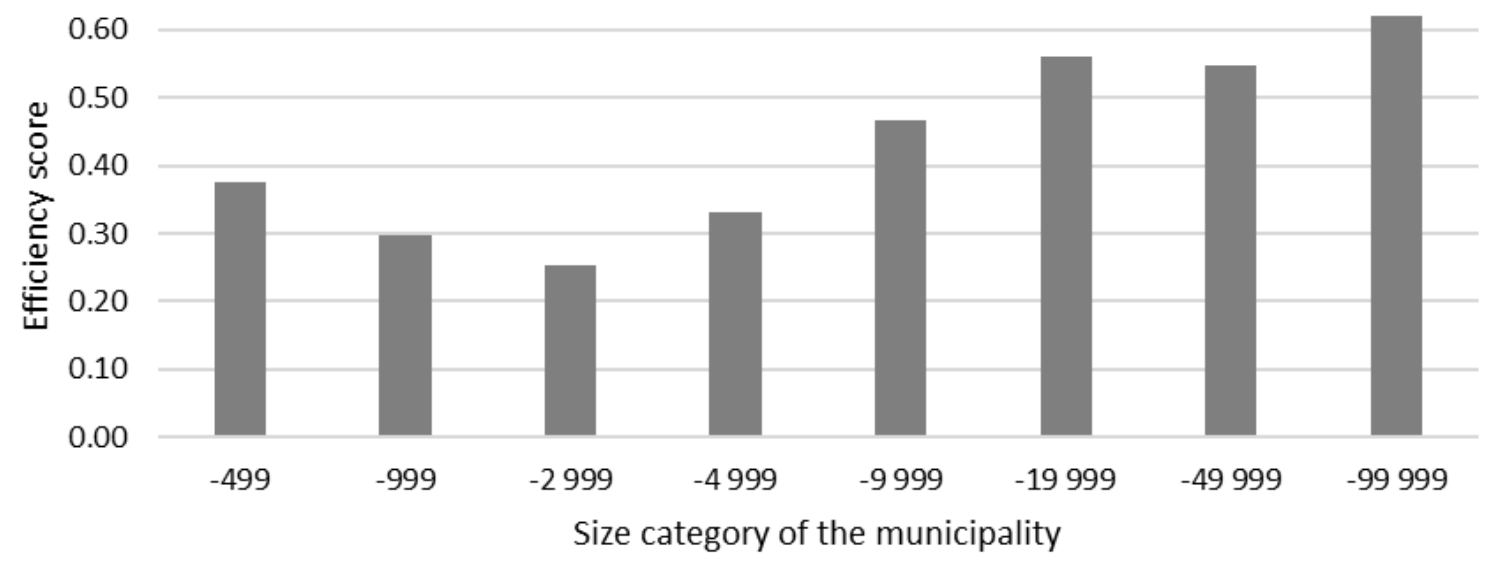

Source: the authors.

\section{Conclusion}

The process of demographic aging is one of the most significant trends of the $21^{\text {st }}$ century. This process is universal in Slovakia, what is manifested by the fact that it takes place in all regions. It is expected accelerating trend of this process in the future decades. The population cohort of over 65 is growing and old dependency ratio and ageing index are increasing. Older people are coming to represent a proportionately larger share of the total population, presenting social, economic and cultural challenges to individuals, families, public welfare systems and society. The main impact of this process is an increasing demand for social services, especially for elderly population. One of providers of social services are municipalities that need to manage limited financial sources, so the issue of efficiency is important. For the assessment of the efficiency of Slovak municipalities divided into regionsize categories was used output oriented AR model under the variable returns to scale.

The efficiency of Slovak municipalities grouped in region-size categories is relatively very low. According to the results arising from Table 7 and Figure 2, we conclude that municipalities with less than 4999 inhabitants are more inefficient in providing social services for elderly inhabitants.

We can identify several reasons of this unfavorable outcome in efficiency analysis of municipality expenditures for elderly people:

- administrative failures (if expenditure has not been placed in the correct category of economic classification of the budgetary classification),

- services provided also by non-profit subjects (if in the region-size categories are higher number of non-profit organizations providing services for elderly people),

- services provided on the basis of informal volunteering and community help, way of life and closer interpersonal relationships in villages and smaller towns,

- individual problems (unfamiliarity of the possibilities of the assistance, problematic achievement of the conditions of the aid),

- economic reason (share of personal income tax hardly cover the operational costs of the municipality and other incomes are not sufficient),

- different priorities of municipalities in providing of services resulting from original competencies.

These findings together with the fact that municipalities are responsible for more than 4300 powers create space for efficiency analysis in other areas such as providing other public services education etc. by municipalities. 


\section{Acknowledgements}

The paper was supported by the grant scheme VEGA No.1/0621/17 "Decision-making process of Slovak households about allocation of time for paid and unpaid work and household strategies' impact on selected areas of the economic practice". The paper was also supported by the grant scheme VEGA No. 1/0151/18 "The impact of local taxes proceeds on performance of local government tasks in both economically developed and lagging regions in the context of industry 4.0 ".

\section{References}

[1] Act No. 369/1990 Coll. on municipal constitution.

[2] Act No. 416/2001 Coll. on transfer of certain powers from state administration bodies to municipalities and higher territorial units.

[3] Act No. 448/2008 Coll. on social services.

[4] Act No. 564/2004 Coll. on budget determination of income tax yields to regional selfgovernment and on amendments and supplements to certain laws.

[5] Benito-Lopez, B., del Rocio Moreno-Enguix, M., Solana-Ibanez, J. 2011. Determinants of efficiency in the provision of municipal street-cleaning and refuse collection services. In Waste Management, 2011, vol. 31, iss. 6, pp. 1099-1108.

[6] Cooper W. W., Seiford L. M., Tone K. 2007. Data envelopment analysis: A comprehensive text with models, applications, references and DEA-Solver software. Heidelberg : Springer, 2007. ISBN 10 0-387-45281-8.

[7] Decree of the Government No. 668/2004 Coll. on distribution of income tax yields to the local government.

[8] D'Inverno, G., Carosi, L., Ravagli, L. 2018. Global public spending efficiency in Tuscan municipalities. In Journal of Socio-Economic Planning Sciences, 2018, vol. 61, pp. 102-113.

[9] Hužvár, M., Rigová. Z., Sýkorová, K. 2016. Efficiency of municipal governments in Slovakia. In Data envelopment analysis and its applications. Proceedings of the 13th International conference on data envelopment analysis, Braunschweig : Technische Universität, 2016, vol. 1, pp. 61-66. ISBN 978-1-85449-497-9.

[10] Kutlar A., Bakirci F., Yüksel F. 2012. An analysis on the economic effectiveness of municipalities in Turkey. In African Journal of Marketing Management, 2012, vol. 4, pp. 80-98.

[11]Liptáková, K. 2018. Kompetencie miestnej samosprávy a jej normotvorba v kontexte miestnych daní na Slovensku. In Bratislavské právnické fórum 2018: ústavnoprávne východiská finančného práva. Bratislava : Comenius University in Bratislava, 2018, pp. 56-66. ISBN 978-80-7160-475-4.

[12]Ministry of Finance of the Slovak Republic 2018. Fiscal decentralization: System financing of the local governments. [cit. 2019-03-16] https://www.finance.gov.sk/en/ finance/public-finance/fiscal-decentralization/the-process-fiscal-decentralization/.

[13] Ministry of Labour, Social Affairs and Family of the Slovak Republic 2014. The national priorities of social services development for 2015 - 2020. [cit. 2019-03-15] https:// www.employment.gov.sk /sk/rodina-socialna-pomoc / socialne-sluzby / narodne-priorityrozvoja- socialnych-sluzieb.html.

[14]Narbon-Perpina, I., Balaguer-Coll, M., Tortosa-Ausina, E. 2019. Evaluating local government performance in times of crisis. In Journal of Local Government Studies, 2019, vol. 45, iss. 1, pp. 64-100. 
[15]Páleník, V. et al. 2012. Strieborná ekonomika v slovenskom, európskom a svetovom kontexte. Bratislava : Economic Institute of the Slovak Academy of Sciences, 2012. ISBN 978-807144-205-9.

[16] Vaňo, B. 2015. Súčasný a očakávaný populačný vývoj na Slovensku a jeho spoločenské a ekonomické dopady. Bratislava : Prognostic Institute of the Slovak Academy of Sciences, 2015. [cit. 2019-03-22] http://www.prog. sav.sk/archive-forecasting-work. 